\title{
Public Policy and the Ageing Workforce in the United States ${ }^{1}$
}

\author{
Sara E. Rix \\ Public Policy Institute, AARP, Washington, DC, U.S.A. \\ E-mail: srix@aarp.org
}

Despite an ageing work force and the impending retirement of millions of baby boomers that could lead to serious labour, skills, and occupational shortages, older workers are not high on the policy agenda in the United States. Nonetheless, labour force participation rates for the older population have been rising, and public opinion polls reveal a sizeable demand for post-retirement employment. The challenge lies in meeting that demand and fostering longer worklives on the part of even more older Americans. A substantial public policy response is by no means certain, although raising the retirement age is likely to feature prominently in the debate on Social Security reform.

\section{Introduction}

By focusing on the development of the policies, programs, and employment arrangements necessary to extend the work life of the growing numbers of older employees, the nation can ensure future supplies of skilled workers, bolster economic growth, and help secure retirement income adequacy for many working Americans.

US General Accounting Office (2001: 34)

With 76 million baby boomers marching more or less resolutely into and through middle age, the US's workforce is getting older. Presently, about 14 per cent of the labour force is aged 55 or over, a figure that is projected to rise to nearly 17 per cent in 2010 and to over 19 per cent in 2015 (Toossi, 2002). According to the US Bureau of Labor Statistics, the median age of the labor force may reach 40.5 years in 2015, nearly six years higher than it was in 1980 (ibid.).

In 2012, the oldest boomers will turn 66, the age of eligibility for full Social Security benefits, or the so-called 'normal retirement age'. The wave of retirements anticipated about this time, coupled with relatively little growth in the working-age population under age 55, has many labour analysts concerned about labour and skills shortages. Moreover, by 2017 , the Social Security system will begin paying out more in benefits than it generates in revenues, necessitating reliance on interest income and eventually a drawing down of trust fund reserves. Absent reform, the reserves will be exhausted by the early 2040s, at which time Social Security will be able to pay less than three-quarters of promised benefits. Various proposals to restore long-term solvency to the Social Security system aim to lengthen the worklife, generally via an increase in the normal retirement age.

For years, economists, labour analysts and older worker advocates have debated the feasibility of extending worklives. Scholarly analyses of longitudinal data sets such as the 'Health and Retirement Study' have greatly enhanced our understanding of older workers and their work and retirement decisions. Additional research points to improved health status and declining disability at older ages, indicating that more workers could push 
back the date of retirement without undue health consequences. A number of public opinion polls document interest on the part of older Americans in working in retirement (e.g., Taylor, 1999; Salisbury et al., 2001; AARP, 2002b). Government agencies as well as major associations and industry groups have attempted to alert public- and privatesector policymakers to the challenges posed by an ageing workforce (e.g., Committee for Economic Development, 1999; US General Accounting Office, 2001). The ageing workforce has even featured prominently in major newspaper and magazine articles. Nonetheless, older workers are not high on the nation's public policy agenda.

\section{Responding to the ageing workforce}

In a 2001 report produced for a Congressional subcommittee, the US General Accounting Office (GAO), the federal agency that serves as the audit, evaluation, and investigative arm of Congress, called for the 'relevant government agencies [to] work together to identify sound policies to extend the worklife of older Americans, including those legal changes that would foster creative solutions to extending workers' careers'. GAO warned that such an undertaking was needed to 'address the potentially serious implications' of the ageing labour force and 'avoid possibly acute occupational shortages' (US General Accounting Office, 2001: 34).

As of late summer 2003, those agencies had yet to act on GAO's recommendation. Nor has there been much action elsewhere in government since Congress eliminated the Social Security retirement earnings test, or benefit reduction, for employed beneficiaries above the normal retirement age in 2000. The ERISA Advisory Council, established to advise the Secretary of Labor on matters pertaining to the Secretary's functions under the Employee Retirement Income Security Act (ERISA), has offered a number of recommendations to enhance and promote phased retirement (ERISA Advisory Council, 2000), and a phased retirement bill has been introduced in Congress. In addition, the Internal Revenue Service and US Treasury have requested public comment on issues relating to phased retirement under defined benefit plans. However, the sense of urgency that underlies efforts to keep people working longer in countries such as Germany is lacking in the United States.

For one thing, the public pension system in the US is in less dire straits than the systems of many other industrialised countries whose populations are older and whose pension programmes are significantly more generous and, hence, more costly. In the United States, Social Security insolvency is still decades away, and, although there seems to be general consensus that the sooner reforms are made the less drastic they need be, Social Security remains a political minefield. Reform will inevitably involve tax increases and/or benefit cuts, neither of which is likely to appeal to the public or its elected officials. Reluctance to tackle reform that might lead to increases in the early and normal retirement ages is understandable, especially in light of public opposition to such increases (see Rix, 1999 for a summary of public opinion polls on raising the retirement age). Indeed, one of the early contenders for the 2004 Democratic presidential nomination initially endorsed raising the retirement age but backed off as his candidacy gained momentum, asserting that his campaign had found better ways to ensure the financial well-being of Social Security (VandeHei, 2003).

The status of the US Social Security trust funds might be bleaker were it not for the relatively high labour force participation rates of older Americans compared with many 
Table 1 Labour force participation rates for older persons, selected countries, 1999/2000 (percentages)

\begin{tabular}{lllllc}
\hline \hline Country & Aged 55-64 & Aged 65+ & Country & Aged 55-64 & Aged 65+ \\
\hline Australia & 46.9 & 5.7 & Japan & 66.5 & 22.6 \\
Austria & 30.7 & 2.8 & Luxembourg & 26.5 & 1.2 \\
Belgium & 26.2 & 1.9 & Netherlands & 36.3 & - \\
Canada & 51.2 & 6.0 & Norway & 68.0 & 11.1 \\
Denmark & 56.6 & 1.9 & Portugal & 52.4 & 17.6 \\
Finland & 46.6 & 3.9 & Spain & 38.7 & 1.6 \\
France & 37.2 & - & Sweden & 68.6 & 7.3 \\
Germany & 44.7 & 2.8 & Switzerland & 72.0 & 10.5 \\
Ireland & 45.7 & 8.0 & United Kingdom & 52.1 & 5.4 \\
Italy & 28.3 & 3.4 & United States & 59.2 & 12.8 \\
\hline \hline
\end{tabular}

Source: International Labour Office (2002).

other industrialized countries, where, for some, hardly anyone remains in the labour force after age 65 (Table 1). Although there are notable exceptions, participation rates are considerably lower in most countries for the 55-64 age group as well.

\section{An end to ever earlier retirement?}

After decades of decline due to the earlier retirement of men, the labour force participation rates for older Americans stabilized in the mid 1980s and began to inch upwards. Between 1985 and 2002, the rate for the total 55-plus population rose from a reported 30.3 per cent to 34.5 per cent; ${ }^{2}$ increases occurred among whites, blacks and Hispanics. In recent years, increases have been especially apparent in certain age groups within the 55-plus population. For example, the participation rate for men aged 65-69 rose from 26.8 per cent to 32.2 per cent between 1994 and 2002 alone, while that for 55-64-year-old women rose from 48.9 per cent to 55.1 per cent.

A number of developments may have contributed to these labour force increases, including stagnation in private pension coverage expansion since the mid 1970s and the trend toward defined contribution (DC) pension plan coverage at the expense of defined benefit (DB) plans. By 1998, 56 per cent of active pension plan participants had DC plans as their primary pension plan, up from 13 per cent in 1975 (Rajnes, 2002). DC plans are inherently riskier and their outcomes thus less certain than DB plans, as workers who heavily invested in the stock market have recently discovered. Many workers who have lost money in the market report planning to postpone retirement (AARP, 2002a; Employee Benefit Research Institute, 2003).

Defined contribution plans are work-neutral. Under defined benefit plans, in contrast, participants who remain on the job after an often early retirement age may find that the increase in pension benefits realized as a result of delaying retirement does not make up for the benefits they forego while continuing to work (Kotlikoff and Wise, 1987). Because such problems do not occur under DC plans, workers covered by these plans might feel less pressure to retire prematurely.

Slowing population growth might also have had an impact on employment opportunities for older workers. By 1985, the youngest boomers had turned 21 and were 
or would soon be in the labour force; they were followed by a considerably smaller cohort of labour force entrants. Employers facing labour shortages might have turned to older workers to meet some of their staffing needs. At the same time, middle-aged women may have been entering or remaining longer in the workforce to qualify for Social Security and/ or private pension benefits.

Burkhauser and Quinn (1997) contend that a shift from anti-work to work-neutral policies has contributed to the increase in labour force participation at upper ages. Noted changes include the increase in and eventual elimination of the mandatory retirement age under the Age Discrimination in Employment Act (ADEA); liberalisation and eventual elimination of the Social Security retirement earnings test for working beneficiaries above the normal retirement age; a more actuarially fair delayed retirement credit paid to workers who postpone collecting Social Security benefits after the normal retirement age; and a gradual increasing of the age of eligibility for full Social Security benefits from 65 to 67 .

Johnson (2002), on the other hand, debunks some of the common explanations for the growing labour supply of older men, arguing, for example, that this rise in participation rates began well before the retirement age increase went into effect, so that could not be a factor. Nor, according to his analyses, are changes in private pensions and slower labour force growth sufficient explanations. Lowering the penalties to work, though difficult to prove statistically, seems the one explanation that might have had some impact, but only for men aged 65 and over. The upshot is that the reversal remains a puzzle - and certainly a development warranting more research. Until more is known about it, Johnson cautions policymakers to 'be careful about basing policy on the assumption that male retirement ages will continue to increase' (ibid.: 20).

Given the European Union directive to member states to draft legislation banning age discrimination in employment by December 2006, the extent to which the Age Discrimination in Employment Act might be responsible for some of the increase in labour force participation rates at older ages in the United States is a matter of some interest. Schulz (1995: 82-84) finds little evidence that mandatory retirement rules precipitated the retirement of a sizeable percentage of Americans, as most workers had been retiring earlier than the mandatory retirement ages that were legal before the enactment of the ADEA and subsequent amendments. ${ }^{3}$ It is hard to see how elimination of mandatory retirement in 1986 could have had much of an impact on participation rates, since so few workers had been remaining in the labour force until age 70, the legal retirement age at that time.

The impact of the ADEA on the employment opportunities of older workers is less certain, in part because of the difficulty proving that age discrimination, per se, as opposed to other factors, is responsible for the adverse employment experiences of older workers (see, e.g., Adams and Neumark, 2002). That many older workers perceive age discrimination is a problem is reflected in survey data (AARP, 2002b), as well as in the number of age charges filed with the Equal Employment Opportunity Commission, the federal agency with jurisdiction over the ADEA (www.eeoc.gov). ${ }^{4}$ That the courts also view age discrimination as a problem is evident in some substantial judgements in favour of plaintiffs, although only a small minority of age charges is ever litigated.

Since few employers today are likely to admit that they discriminate against older workers, it is impossible to know whether age discrimination is more or less prevalent than it was before the ADEA. On the one hand, the amount of damages and monetary relief paid to alleged plaintiffs of age discrimination, coupled with the negative publicity associated with discrimination charges, should be making employers more aware. On the other 
hand, discrimination against older workers may have become more subtle and harder to detect. Employers may also be using early retirement incentive programmes to divest themselves legally of older workers. In one of the few efforts to assess the effectiveness of age discrimination legislation, Neumark (2001: 35) concludes that, on balance, 'a relatively positive assessment... is more warranted than a negative assessment', although the available evidence is not decisive. Nonetheless, the ADEA does offer older workers protection and the promise of redress, which they lacked prior to 1967.

\section{A look to the future}

According to projections from the U.S. Bureau of Labor Statistics, the participation rate for the 55-plus population will increase by 5.6 percentage points between 2000 and 2015, but none of that increase is expected to occur among men ages 55-64 (Toossi, 2002). Some observers insist that these projections underestimate likely future participation rates, as boomers are widely expected to redefine retirement in ways that will include more labour force activity later in life. Johnson (2000: 20) speculates that the 'taste for work' may have increased, although he says there is no obvious reason why that might have occurred precisely in 1985 .

Regardless of what may have happened in 1985, very high percentages of workers in recent years have been asserting that they plan on working in retirement. Among boomers, that figure approaches 70-80 per cent who expect to work at least part time when they retire (AARP 1998, 2002b). Comparable figures have been noted in other surveys and for other age groups. While many workers, especially after the market downturn of recent years, say they will need to work, a higher percentage expects to work because they enjoy what they do or want to remain active. As boomers get closer to retirement age, poor health, a lack of alternative work options, and various work-related problems may increase the appeal of retirement, but for many of the better-educated, healthier boomers who have two or more decades of life ahead of them, attachment to the labour force may remain strong.

Obviously, people work because they need the income, but something other than money does seem to be keeping many older persons in the workforce, especially those who remain at work after conventional retirement age. One might expect that wages would comprise a higher percentage of the income of less affluent older persons, i.e. those with a greater need to work, but the opposite is the case: earnings account for 35 per cent of income of the 65-plus population in the highest income quintile but only 1 per cent of the income of those in the lowest quintile (Social Security Administration, 2002). Haider and Loughran (2001) found that the labour supply of the 65-plus population was concentrated among the healthiest, best educated, and wealthiest, yet those workers tended to be earning low wages. Flexibility in work was common, however, which led Haider and Loughran to conclude that the elderly are particularly willing to purchase jobs that they enjoy and allow them the flexibility they desire at the expense of low financial returns' (ibid.: 4).

Yet, however much they say they want to work, older Americans continue to retire early, with 62 the most common age at which Social Security retired worker benefits are awarded. Despite the increases in labour force participation at upper ages, only a minority continue working beyond the normal retirement age. A sizeable proportion of workers retire before they planned to (Employee Benefit Research Institute, 2003), and once out 
of the labour force, few express interest in getting back in. Barely more than 2 per cent of the 38.4 million persons aged 55 and older who were not in the labour force in 2002 said they wanted a job (US Bureau of Labor Statistics, 2003). Although more non-working older persons might express interest in work if the available options were more attractive or if they felt their chances of finding work were better, it appears that most people adjust quickly and well to retirement (Schulz, 1988). Thus, if the goal is longer worklives, it may have to be accomplished before workers reach a stage that retirement is inevitable, perhaps by focusing on workers in early midlife (US General Accounting Office, 2001).

\section{Fostering longer worklives}

Interest in post-retirement employment is apparently not a new sentiment, although it may be more prevalent today. Over half of workers surveyed in the late 1970s said they would prefer to retire and find another job or not to retire at all (Louis Harris and Associates, Inc., 1979). A key question is how best to capitalise on the presumed desire for continued employment on the part of the millions of middle-aged workers who say they want to work, especially in view of the fact that workers give mixed signals. For example, according to one survey, 80 per cent of boomers expect to work in retirement, but the age at which they would 'like to stop working for pay altogether/completely' i.e., leave the labour force - is less than 60 (unpublished tabulations from AARP, 1998). In addition, workers are staunchly opposed to being pressured to work longer as a result of an increase in Social Security's retirement age.

Marilyn Moon sees a higher normal retirement age as a 'favorite proposal of workaholics' but of nobody else (Moon cited in Wildavsky, 1998: 1563). Ideally, any increase in retirement age would be the result of voluntary action on the part of workers to postpone retirement. Almost everyone is likely to favour an expansion of employment opportunities that foster a retirement-age increase, as long as they are not mandated on employers, do not increase labour costs, do not add administrative burdens on employers, do not make it more difficult to get rid of non-performers, do not treat older workers as second-class citizens, do not limit promotion opportunities for younger workers, and do not become costly government programmes.

There is no shortage of proposals to expand employment opportunities for older workers; however, many of them would be objectionable to one group or another. For example, pro-rata benefits for part-time jobs might increase the appeal of those jobs to older workers, but employers would balk at the added costs. Japan's mandatory retirement followed by the rehiring of many retirees contributes to its higher labour force participation rate at older ages. However, the lower wages and diminished status accord older workers second-class status and, in any case, would run foul of the ADEA in the United States. An expansion of the limited government-funded older worker training programmes would be expensive and seems doomed in the present climate.

Moreover, if Johnson (2002) is correct and the reasons for rising participation rates on the part of older men remain a puzzle, then the impact of potential policy changes is uncertain. Too little is known about where workers expect to be employed in retirement; how reasonable their expectations are; and what it would actually take to keep them employed. One thing does seem clear - more and better part-time work might be an answer.

Workers indicate that they would like to scale back their work hours and express interest in phasing into retirement. Nevertheless, although there exist a variety of ways 
to ease into retirement - e.g., post-retirement consulting, part-time work with a new employer, and temporary agency work - formal phased retirement programmes that enable workers to move gradually into retirement by working fewer hours with their current employer are rare in the United States.

Various legal and regulatory impediments limit employers' ability to offer phased retirement options to current employees. Under ERISA, for example, employers risk losing the tax-favoured status of their defined benefit pension plans if they make in-service distributions to workers before a plan's normal retirement age. Workers who might want to work less but who would need to supplement lost wages with pension benefits must retire and find part-time work elsewhere. There is also a question of whether a lower salary associated with fewer work hours can result in reduced pensions for workers in final average-pay pension plans; such reductions would hardly induce workers to phase into retirement. (For a thorough discussion of the barriers to implementing phased retirement programmes, see Chen and Scott, 2003 and Penner et al., 2002.)

\section{Conclusion}

In 1981, the chairman and ranking minority member of the U.S. Senate Special Committee on Aging called on all sectors of the economy to work together to expand employment opportunities for older workers. The Senators stressed the need for a national older worker policy that 'will become all the more important as our society ages ... to achieve such a policy, the debate must begin now' (US Senate, 1981: iii). Society has aged, but debate on a national older worker policy has yet to begin.

In the ideal world, employers, unions, government, and the general public would be taking advantage of the few years available before boomers reach retirement age to 'develop sound policies, programmes, and practices to respond to the demographic challenge' of an ageing society (US Government Accounting Office, 2001: 33), perhaps even crafting a national older worker policy. In the real world, however, the press of more urgent matters means that matters that can wait typically do. Public policymakers will assuredly tackle a number of older worker issues in coming years, as they have done in the past, although a comprehensive older worker employment policy seems doubtful. Moreover, most of the action on older workers will likely occur in the private sector, as employers respond to labour and skills shortages and if boomers act on their stated desire to work longer by making demands on employers for more flexible and attractive work options. The path might be smoother if the interested parties started working together now - indeed, it might have been smoother still had they started in 1981. Nonetheless, the economy accommodated the vast number of boomers when they entered the labour force; it should be able to accommodate them if they choose to delay exiting it.

\section{Notes}

1 The views expressed in this article are those of the author and do not necessarily represent the policy or perspectives of AARP.

2 In 1994, a major redesign of the survey used to estimate labour force participation rates in the US led to the conclusion that prior data collection had underestimated the participation of certain marginal groups, among them older workers (Polivka and Miller, 1998). Adjustment for this underestimate yields a participation rate of 31.2 per cent for the 55-plus population in 1985 rather the unadjusted 30.3 per cent cited above. Older Americans' labour force participation increase has therefore been somewhat 
less pronounced than often reported. However, the increase has been especially marked since 1994; no adjustment is required for figures from this date on.

3 Schulz has calculated, for example, that fewer than 10 per cent of retired men in a sample of Social Security beneficiaries were prevented from working by mandatory retirement policies that were legal at the time they retired.

4 After falling in the boom years of the late 1990s, age discrimination charges began to rise once again in 2000.

\section{References}

AARP (1998), Boomers Look Toward Retirement, Washington, DC: AARP.

AARP (2002a), Impact of Stock Market Decline on 50-70 Year Old Investors, Washington, DC: AARP.

AARP (2002b), Staying Ahead of the Curve: The AARP Work and Career Study, Washington, DC: AARP.

Adams, S. and Neumark, D. (2002, July), Age Discrimination in US Labor Markets: A Review of the Evidence (preliminary) [Online], Available: http://www.uwm.edu/People/sjadams/lit\%20review\% 20sample.pdf [14/10/03].

Burkhauser, R.V. and Quinn, J.F. (1997), 'Pro-work policy proposals for older Americans in the 21st century', Policy Brief No. 9, Maxwell School of Citizenship and Public Affairs, Center for Policy Research, Syracuse University, Syracuse, NY.

Chen, Y.-P. and Scott, J.C. (2003), 'Gradual retirement: an additional option in work and retirement', North American Actuarial Journal, 7, 3, 62-74.

Committee for Economic Development (1999), New Opportunities for Older Workers, Washington, DC: Committee for Economic Development.

Employee Benefit Research Institute (2003), The 2003 Retirement Confidence Survey: Summary of Findings [Online], Available: http://www.ebri.org/rcs/2003/03rcssof.pdf [31/8/03].

ERISA Advisory Council (2000), Report of the Working Group on Phased Retirement [Online], Available: http://www.dol.gov/ebsa/publications/phasedr1.htm [30/8/03].

Haider, S. and Loughran, D. (2001), 'Elderly labor supply: work or play?', Paper prepared for the Third Annual Conference of the Retirement Research Consortium, Washington, DC, 17-18 May.

International Labour Office (2002), Key Indicators of the Labour Market 2001-2002, Geneva: International Labour Office.

Johnson, R. (2002), 'The puzzle of later male retirement', Economic Review, Third Quarter, 5-26.

Kotlikoff, L.J. and Wise, D.A. (1987), 'The incentive effects of private pension plans', in Z. Bodie, J.B. Shoven, and D.A. Wise (eds), Issues in Pension Economics, Chicago: University of Chicago Press.

Louis Harris and Associates, Inc. (1979), 1979 Study of American Attitudes Toward Pensions and Retirement, New York: Johnson \& Higgins.

Neumark, D. (2001), 'Age discrimination legislation in the United States', Working Paper 8152, National Bureau of Economic Research, Cambridge, MA.

Penner, R.G., Perun, P., and Steuerle, C.E. (2002), Legal and Institutional Impediments to Partial Retirement and Part-time Work by Older Workers, Washington, DC: Urban Institute.

Polivka, A.E. and Miller, S.M. (1998), 'The CPS after the redesign: refocusing the economic lens', in J. Haltiwanger, M.E. Manser, and R. Topel (eds), Labor Statistics Measurement Issues, Chicago: University of Chicago Press, pp. 249-286.

Rajnes, D. (2002), 'An evolving pension system: trends in defined benefit and defined contribution plans', EBRI Issue Brief, No. 249, September.

Rix, S.E. (1999), 'Social Security reform: rethinking retirement-age policy - A look at raising Social Security's retirement age', Issue Brief, No. 40, Washington, DC: AARP.

Salisbury, D., Turyn, T., and Helman, R. (2001), 'EBRI 2001 retirement surveys: Retirement Confidence Survey (RCS), Minority RCS, and Small Employer Retirement Survey (SERS)', EBRI Issue Brief, No. 234, June. 
Schulz, J.H. (1988), 'Job matching in an ageing society: barriers to the utilization of older workers'. Paper presented at the Gerontological Society of America annual meeting, San Francisco.

Schulz, J.H. (1995), The Economics of Aging, 6th edn, Westport, CT: Auburn House.

Social Security Administration (2002), Income of the Population 55 or Older, 2000, Washington, DC: Social Security Administration.

Social Security Advisory Board (1999), Forum on Implications of Raising the Social Security Retirement Age, Social Security Advisory Board, Washington, DC.

Taylor, H. (1999), '3.7 million people over 55 not working now are ready, willing and able to work', The Harris Poll, No. 62, 27 October.

Toossi, M. (2002), 'A century of change: the US labor force, 1950-2050', Monthly Labor Review, 125, 5, $15-28$.

US Bureau of Labor Statistics (2003), Employment and Earnings, Washington, DC: Government Printing Office, 50, 1.

US General Accounting Office (2001), 'Older workers: demographic trends pose challenges for employers and workers', US General Accounting Office, GAO-02-85, Washington, DC.

US Senate, Special Committee on Aging (1981), 'Toward a national older worker policy', an Information Paper, US Government Printing Office, Washington, DC.

VandeHei, J. (2003), 'Dean invites more scrutiny by switching key stances', Washington Post, 30 August.

Wildavsky, B. (1998), 'Working solutions', National Journal, 4 July, 1560-1564. 